\title{
PENGARUH PEMBELAJARAN DARING TERHADAP HASIL BELAJAR MATA PELAJARAN KEWIRAUSAHAAN DI SMK MANBA'UL ULUM BEKASI
}

\author{
Sophia Mahmuda ${ }^{1}$, Chientya Annisa Rahman Putrie ${ }^{2(*)}$ \\ Universitas Panca Sakti, Bekasi, Indonesia ${ }^{12}$ \\ sophiamahmuda30@gmail.com ${ }^{1}$, chientya2725@gmail.com ${ }^{2}$
}

\section{Received: 13 Juli 2021 \\ Revised: 10 Agustus 2021 \\ Accepted: 23 Agustus 2021}

\begin{abstract}
Penelitian ini bertujuan untuk mengetahui pengaruh pembelajaran daring (X) terhadap hasil belajar mata pelajaran kewirausahaan (Y) di SMK Manba'ul Ulum Bekasi. Penelitian ini menggunakan penelitian kuantitatif. Teknik pengumpulan data menggunakan angket secara online menggunakan google form dan menggunakan random sampling. Populasi dalam penelitian ini adalah seluruh siswa siswi SMK Manba'ul Ulum Bekasi sejumlah 59 siswa. Jumlah sampel dalam penelitian ini adalah 59 siswa. Analisis data menggunakan analisis regresi linear sederhana melalui perhitungan dengan bantuan program IBM SPSS Statistic 25. Skor penilaian menggunakan skala likert. Hasil penelitian menunjukkan adanya "Pengaruh Pembelajaran Daring berpengaruh positif terhadap hasil belajar Mata Pelajaran Kewirausahaan di SMK Manba'ul Ulum Bekasi”. Persamaan Regresi Linear Diperoleh persamaan linear sederhana $\mathrm{Y}=$ $68,231+0,283 \mathrm{X}$. Dari hasil analisis diperoleh thit $=3,927$ dan $\mathrm{p}$-value $=$ $0,000 / 2=0<0,05$ atau Ho di tolak. Dengan demikian "Pembelajaran Daring berpengaruh positif terhadap Hasil Belajar mata pelajaran Kewirausahaan di SMK Manba'ul Ulum Bekasi”. Hal ini dapat dilihat pada table coefficient dari thit dan p-value lebih kecil dari 0,05. Koefisien Determinasinya sebesar terdapat pada tabel di atas yaitu nilai $\mathrm{R}$ Square $=$ $0,213=21,3 \%$ ini berarti variasi variabel hasil belajar mata pelajaran kewirausahaan.
\end{abstract}

Keywords: Pembelajaran Daring, Hasil Belajar, Kewirausahaan

(*) Corresponding Author: $\quad$ Putrie, Chientya2725@gmail.com, 081324679391

How to Cite: Mahmuda, S., \& Putrie, C. A. R. (2021). Pengaruh Pembelajaran Daring Terhadap Hasil Belajar Mata Pelajaran Kewirausahaan Di SMK Manba'ul Ulum Bekasi. Research and Development Journal of Education, 7 (2), 393-402.

\section{INTRODUCTION}

Pembelajaran Daring adalah metode kegiatan belajar mengajar dimana aktivitas belajar mengajar dilakukan secara terpisah. Pemisahan tersebut berupa jarak maupun keadaan yang jauh dari suatu tempat. Dalam Pembelajaran Daring (Dalam Jaringan) juga menggunakan bermacam metode yang dilakukan dikomunikasikan melalui media, dengan demikian Pembelajaran daring diharapkan dapat mengatasi beberapa masalah yang ditimbulkan akibat keterbatasan jarak, tempat dan lingkungan suatu daerah. Salah satu contoh media dalam pembelajaran daring adalah aplikasi Whatsapp, Zoom (Vhalery, Setyastanto, \& Alfilail, 2021), Google Classroom (Vhalery, Alfilail, Robbani, 2021), ataupun google meet dengan adanya aplikasi tersebut guru dan siswa tidak perlu lagi datang ke sekolah, tugas dan pelajaran dapat di berikan secara online.

Pembelajaran Daring adalah Metode pembelajaran yang peserta didik dan pendidiknya berada dilokasi terpisah dari aktivitas belajar tatap muka. Bagian dari pembelajaran jarak jauh ialah menggunakan Pembelajaran Elektronik (E-Learning), 
Pembelajaran Daring (Online), dan Home Learning (Pembelajaran di Rumah). Konsekuensi dari penutupan Lembaga Pendidikan atau Sekolah secara tatap muka yang dirubah dengan belajar dari rumah atau Pembelajaran Daring yang sebagaimana kebijakan pemerintah dengan adanya perubahan sistem KBM atau kegiatan belajar mengajar. Diantaranya pengelola sekolah, orangtua, siswa dan guru harus berpindah ke sistem pembelajaran daring (dalam jaringan), yang lebih dikenal dengan Pembelajaran dari rumah atau Pembelajaran jarak jauh.

Negara Indonesia termasuk negara yang terkena dampak Covid 19, yang berarti Indonesia tidak berbeda dengan negara lain. Meskipun menyadari bahwa kurangnya akses teknologi pembelajaran dan beragamnya latar belakang orang tua, Kementerian Pendidikan dan Kebudayaan Republik Indonesia dengan tegas memberlakukan kebijakan pembelajaran daring (Wahyono, Husamah, \& Budi, 2020). Pembelajaran Kewirausahaan adalah suatu pembelajaran yang berisi tentang nilai-nilai (value), kemampuan (ability) dan perilaku (attitude) dalam menghadapi tantangan hidup untuk memperoleh peluang dengan berbagai risiko yang dihadapi oleh siswa didunia kerja. Pane dan Dasopang (2017) pembelajaran adalah suatu proses yang mempelajari, mengorganisasi lingkungan di sekitar siswa sehingga siswa dapat menumbuhkan dan mendorong siswa melakukan suatu proses belajar. Pembelajaran juga dapat diartikan sebagai interaksi berkelanjutan bukan hanya dipelajari disekolah, dapat juga dipelajari di lingkungan masyarakat ataupun keluarga, dapat mempelajari pengembangan dan pengalaman hidup.

Realisasi pembelajaran daring atau dalam jaringan sudah dianjurkan oleh kementerian pendidikan dan kebudayaan dengan penerapan pembelajaran mandiri selama pandemi COVID-19 (Suharwoto, 2020). Januardi dan Zubaimari (2018) Kewirausahaan yaitu siswa yang mempelajari tentang menanamkan etika, jiwa, dan sikap wirausaha, memberikan bekal pengetahuan kewirausahaan serta memberi bekal keterampilan dibidang barang atau jasa kepada para siswa. Pembelajaran daring atau dalam jaringan merupakan suatu sistem pembelajaran yang saat pandemi ini dirasakan tepat, karena dalam masa pandemi seperti ini kegiatan pembelajaran tidak dapat dilakukan secara langsung dalam kelas atau tatap muka (Harnani, 2020).

Kewirausahaan adalah suatu proses untuk menciptakan tambahan kemakmuran. Proses menciptakan sesuatu yang kreatif dan menarik yang berbeda dengan yang lain dengan menggunakan waktu dan kegiatan disertai modal jasa dan risiko, serta menerima balas jasa. Wirausaha adalah mereka yang melakukan upaya-upaya kreatif dan inovatif dengan cara mengembangkan ide, dan mempelajari sumber daya untuk menemukan peluang (opportunity) dan perbaikan (preparation) hidup. Selain itu, peran keluarga kurang memberikan kontribusi yang berarti dalam mendukung pencapaian dan pembentukan karakter wirausaha siswa. Disebabkan lantaran kurangnya pemahaman terhadap ilmu kewirausahaan, di mana orang tua lebih menginginkan anaknya belajar bersama gurunya karna memudahkan anak untuk melihat secara langsung proses dalam pembelajaran. Untuk mengetahui perkembangan sampai di mana hasil yang telah dicapai oleh seluruh siswa dalam belajar, maka harus dilakukan evaluasi. Untuk menentukan kemajuan yang dicapai maka harus ada kriteria yang mengacu pada tujuan yang telah ditentukan sehingga dapat diketahui seberapa besar pengaruh strategi belajar mengajar terhadap keberhasilan belajar siswa.

Purwanto (2011) hasil belajar adalah perubahan perilaku yang terjadi setelah mengikuti pembelajaran sesuai dengan tujuan pendidikan ada 3 yaitu kognitif, afektif dan psikomotorik. Contoh dari kognitif yaitu kemampuan hapalan, pemahaman, penerapan, analisis, sintesis, dan evaluasi. Afektif yaitu hasil belajar yang terdiri dari penerimaan, organisasi, partisipasi, penilaian, dan karakterisasi. dan psikomotorik yaitu terdiri dari persepsi, gerakan terbimbing, gerakan terbiasa, gerakan kompleks dan kreativititas. 
Menteri Pendidikan dan Kebudayaan mengeluarkan Surat Edaran No 3 tahun 2020 tentang pelaksanaan kegiatan pembelajaran untuk pencegahan penyebaran virus Corona (Covid-19) pada Satuan Pendidikan. Penyebaran virus Corona (Covid-19) di Indonesia telah merubah tatanan kehidupan masyarakat, tidak hanya menyerang negara Indonesia namun juga seluruh dunia. Keberadaan Covid-19 membuat masyarakat untuk memberhentikan aktivitas di luar rumah (PSBB). Masyarakat juga harus menjaga jarak aman atau physical distancing. Pelaksanaan karantina, Memakai masker, menghindari mobilitas, isolasi mandiri yang dihimbau oleh pemerintah berdampak pada sistem pendidikan. Proses pembelajaran yang mana biasa dilaksanakan secara tatap muka di dalam ruang kelas pada lingkungan sekolah, kini berubah menjadi belajar di dalam rumah atau daring. Media pembelajaran daring merupakan salah satu alat komunikasi dalam proses pembelajaran, dikatakan demikian karena di dalam proses pembelajaran terdapat proses penyampaian pesan dari guru kepada siswa. Media pembelajaran dapat diartikan sebagai salah satu faktor eksternal yang berpengaruh terhadap keberhasilan kegiatan pembelajaran, secara umum manfaat media pembelajaran yakni untuk memperlancar interaksi antar guru dengan siswa sehingga pembelajaran lebih efektif dan efisien. Selain media pembelajaran memerlukan kesiapan gadget yang berupa smartphone, laptop, dan tentu paket data internet yang masih dikelola secara mandiri.

Permendikbud no 34 Tahun 2018, pendidikan SMK atau Sekolah Menengah Kejuruan merupakan pendidikan yang mempersiapkan peserta didik terutama untuk bekerja dalam bidang bidang tertentu. Pada pendidikan SMK memberikan adanya bentuk pengembangan bakat, pendidikan dasar keterampilan dan kebiasaan yang mengarah pada dunia kerja, dipandang sebagai latihan keterampilan yang berkreatif. Siswa akan disiapkan dan diajarkan untuk memasuki persaingan di dunia kerja, dengan proses pembelajaran.

SMK Manba'ul Ulum adalah salah satu sekolah di daerah Babelan Bekasi yang sudah menerapkan kemajuan teknologi dalam kegiatan belajar mengajarnya, salah satunya yaitu dengan menggunakan Pembelajaran Daring (Dalam Jaringan). kegiatan yang menggunakan Pembelajaran daring di SMK Manba'ul Ulum antara lain adalah kegiatan belajar mengajar menggunakan aplikasi seperti Zoom, Google Classroom, Whatsapp Grup, Google Meet. pelaksanaan Penilaian Tengah Semester (PTS), Penilaian Akhir Semester (PAS), dan Penilaian Akhir Tahun (PAT). Dimana kegiatan tersebut sudah tidak lagi menggunakan lembar soal, lembar jawaban, alat tulis dan sebagainya, tetapi sudah menggunakan teknologi yang ada, salah satunya dengan menggunakan smartphone dan notebook. Model dual mode. Dalam model ini ada dua kelompok siswa, yaitu kelompok yang pertama, siswa yang belajar tatap muka di kelas, dan kelompok kedua, siswa yang belajar secara jarak jauh atau dengan tatap muka dilakukan dengan sangat minimum. Dua kelompok siswa ini mendapatkan pembelajaran yang sebanding dari pihak sekolah, sekalipun kenyataannya siswa tatap muka memiliki lebih banyak memiliki kemudahan dalam hal akses ke berbagai sumber belajar di kelas.

Berdasarkan hasil penelitian Pengaruh pembelajaran daring terhadap hasil belajar mata pelajaran Kewiausahaan di SMK Manba'ul ulum berpengaruh positif. Saat ini pembelajaran dengan 2 model, Dengan tatap muka yang syaratnya hanya saat materi praktek, dan belajar daring dengan materi pembahasan. Beberapa pengaruh positif saat pembelajaran daring, Guru dan murid tidak perlu bertatap muka secara langsung dalam ruang kelas, karena yang digunakan adalah Smartphone, wifi. Tidak terbatas oleh waktu. Siswa dapat menentukan kapan saja waktu untuk belajar, proses pembelajaran tidak perlu mengganggu waktu. Siswa dapat memilih topik atau bahan ajar sesuai dengan keinginan dan kebutuhan masing-masing. Siswa dapat menanyakan hal-hal yang kurang dipahami secara langsung kepada guru, sehingga keakuratan jawaban dapat terjamin. Pembelajaran Daring ini dilaksanakan secara interaktif, sehingga menarik perhatian siswa. 
Pengaruh negatif saat pembelajaran daring yaitu, listrik padam ketika mengakses program pembelajaran online. Jaringan internet yang buruk. Hal ini membuat siswa kesulitan untuk mengirim atau mengerjakan tugas yang diberikan oleh guru. Komitmen orangtua dan siswa yang tidak menentu. Siswa yang kurang aktif pada saat pembelajaran daring lewat Whatsapp Grup, Zoom, ataupun Google Classroom.

\section{METHODS}

Jenis penelitian yang digunakan adalah kuantitatif. Penelitian kuantitatif yaitu suatu penelitian yang digunakan untuk meneliti pada populasi atau sampel tertentu dengan populasinya yaitu seluruh siswa di SMK Manba'ul Ulum Bekasi, pengumpulan data menggunakan instrumen penelitian, analisis data bersifat kuantitatif atau statistik, yang bertujuan untuk menguji hipotesis yang telah ditetapkan pada statistik. Sugiyono (2017:8) bertujuan untuk mengungkap pengaruh pembelajaran daring terhadap hasil belajar mata pelajaran kewirausahaan SMK Manba'ul Ulum Bekasi. Populasi dalam penelitian ini dilakukan pada siswa-siswi di SMK Manba'ul Ulum Bekasi, waktu penelitian dilaksanakan pada semester genap tahun akademik 2020-2021. Tepatnya bulan Juni sampai dengan Juli 2021. Adapun tahapan pelaksanaan dalam penelitian ini berlangsung selama 1 bulan. Jumlah responden sebanyak 59 siswa sedangkan sampel yang diambil sebanyak 59 siswa. Teknik pengambilan Angket menggunakan Google form, yang dikirim melalui Whatsapp Grup. Penarikan sampel menggunakan random sampling. random sampling adalah suatu metode penarikan dari sebuah populasi atau dengan cara tertentu sehingga siswa populasi memiliki peluang yang sama untuk terpilih atau terambil. Sedangkan teknik analisis yang digunakan dalam penelitian ini adalah Regresi Linear Sederhana.

Dengan menggunakan Skala Likert dengan dengan jumlah butir 25 dan skor yang digunakan dimulai dari 5 (lima) sampai dengan 1 (satu) berdasarkan gradasi jawaban, (Saifuddin Anwar, 2010) Sebagai alat ukur, skala psikologi yang memiliki karakteristik khusus cara membedakannya yaitu dengan cara dari berbagai bentuk alat pengumpulan data yang lain seperti angket (questionnaire), daftar isian, mengisi form, inventori, dan lain-lainnya. Pengukuran Pembelajaran Daring dalam penelitian ini yaitu dengan cara dilakukan untuk mengetahui tingkat jawaban terdiri dari lima pilihan sikap, yang telah disesuaikan dengan butir-butir pernyataan yaitu, SS (sangat setuju), S (setuju), CS (cukup setuju), TS (tidak setuju), STS (sangat tidak setuju).

\section{RESULTS \& DISCUSSION}

\section{Results}

\section{Skor Hasil Belajar Kewirausahaan}

Untuk mengetahui apakah data yang penulis kumpulkan dan diteliti termasuk data berdistribusi normal atau tidak, maka penulis melakukan pengujian dengan menggunakan alat bantuan software yaitu IBM SPSS Statistic 25 yang hasilnya dapat dilihat pada table berikut :

Tabel 1.

Statistik Hasil Belajar

\begin{tabular}{|c|c|c|}
\hline \multicolumn{3}{|c|}{ Hasil Belajar } \\
\hline $\mathrm{N}$ & Valid & 59 \\
\hline
\end{tabular}




\begin{tabular}{lr}
\hline & 0 \\
Mean & 84,00 \\
Std. Error of Mean & 372 \\
Median & 84,00 \\
Mode & 80 \\
Std. Deviation & 2,859 \\
Variance & 8,172 \\
Range & 9 \\
Minimum & 80 \\
Maximum & 89 \\
Sum & 4956 \\
\hline Sumber : IBM Statistic SPSS 25
\end{tabular}

Berikut data hasil analisis dengan Berdasarkan skor hasil belajar mata pelajaran Kewirausahaan 59 responden, diperoleh skor empirik terendah 80 dan skor empirik tertinggi 89. rentang skor 9, Rata-rata skor (mean) sebesar 84,00 simpangan baku 2,859, modus 80 , median 84,00 .

\section{Skor Pembelajaran Daring}

Tabel 2.

Statistik Daring

\begin{tabular}{lcc}
\multicolumn{3}{c}{ Statistik Daring } \\
\hline \multicolumn{2}{c}{ Daring } \\
\hline \multicolumn{1}{c}{ Valid } & 59 \\
& Missin & 0 \\
Mean & \\
Std. Error of Mean & 55,63 \\
Median & 58,00 \\
Mode & 60 \\
Std. Deviation & 4,653 \\
Variance & 21,652 \\
Range & 14 \\
Minimum & 46 \\
Maximum & 60 \\
Sum & 3282 \\
\hline Sumber : IBM Statistic SPSS 25
\end{tabular}

Berikut data hasil analisis dengan Berdasarkan skor hasil belajar mata pelajaran Kewirausahaan 59 responden, diperoleh skor empirik terendah 46 dan skor empirik tertinggi 60. rentang skor 14, Rata-rata skor (mean) sebesar 55,63 simpangan baku 4,653, modus 60 , median 58,00

A. Pengujian Prasyarat Analisis Data

1. Uji Normalitas

Untuk mengetahui apakah data yang penulis kumpulkan dan diteliti termasuk data berdistribusi normal atau tidak, maka penulis melakukan pengujian dengan menggunakan alat bantuan software yaitu IBM SPSS Statistic 25 yang hasilnya dapat dilihat pada table berikut : 
a) Uji Normalitas Skor Hasil Belajar

Tabel 3.

Uji Normalitas Hasil Belajar

\begin{tabular}{ccc}
\hline \multicolumn{3}{c}{ One-Sample Kolmogorov-Smirnov Test } \\
\hline & & Hasil \\
$\mathrm{N}$ & & Belajar \\
Normal Parameters & Mean & 59 \\
& Std. & 24,00 \\
& Deviation & \\
Most Extreme & Absolute &, 165 \\
Differences & Positive &, 128 \\
& Negative &,- 165 \\
Kolmogorov-Smirnov Z &, 165 \\
Asymp. Sig. (2-tailed) &, 000 \\
\hline
\end{tabular}

Sumber: IBM Statistic SPSS 25

Dari data diatas,diperoleh Kolmogorov-SmirnovZ sebesar 0,165, angka ini sama dengan hasil secara manual dan nilai Asymp. Sig. (2-tailed) sebesar 0,000 atau dapat ditulis sebagai nilai probabilitas ( $\mathrm{p}$-value) $=0,000<0,05$ atau Ho diterima. Dengan demikian, data Hasil Belajar mata pelajaran Kewirausahaan berdistribusi Normal.

b) Uji Normalitas Skor Daring

Tabel 4.

Uji Normalitas Daring

\begin{tabular}{ccr}
\hline \multicolumn{3}{c}{ One-Sample Kolmogorov-Smirnov Test } \\
\hline \multirow{2}{*}{$\mathrm{N}^{\mathrm{a}, \mathrm{b}}$} & & Daring \\
& Mean & 59 \\
& Std. & 4,653 \\
& Deviation & \\
Most Extreme Differences & Absolute &, 220 \\
& Positive &, 174 \\
& Negative &,- 220 \\
Kolmogorov-Smirnov Z &, 100 \\
Asymp. Sig. (2-tailed) &, $000^{\mathrm{c}}$ \\
\hline Sumber: IBM Statistic SPSS 25
\end{tabular}

Dari data diatas,diperoleh Kolmogorov-SmirnovZ sebesar 0,100, angka ini sama dengan hasil secara manual dan nilai Asymp. Sig. (2-tailed) sebesar 0,000 atau dapat ditulis sebagai nilai probabilitas ( $\mathrm{p}$-value) $=0,000<0,05$ atau Ho diterima. Dengan demkian, data Hasil Belajar mata pelajaran Kewirausahaan berdistribusi Normal.

2. Uji Homogenitas

Tabel 5.

Uji Homogenitas

Test of Homogeneity of Variances

\begin{tabular}{llll}
\hline Levene Statistic & df1 & df2 & Sig. \\
\hline
\end{tabular}




\begin{tabular}{|c|c|c|c|}
\hline 1,291 & 2 & 56 & ,283 \\
\hline
\end{tabular}

Dari hasil analisis pada tabel Test of Homogeneity of Variances,diperoleh Levene Statistic $=1,291 ; \mathrm{df} 1=2 ; \mathrm{df} 2=56$, dan p-value $=0,283>0,05$ atau Ho diterima. Dengan demikian, kedua kelompok data berasal dari kelompok yang homogen.

3. Uji Hipotesis

a) Persamaan Regresi Linear

Tabel 6.

Koefisien Regresi Linear

\begin{tabular}{|c|c|c|c|c|c|}
\hline \multirow[t]{2}{*}{ Model } & \multicolumn{2}{|c|}{$\begin{array}{c}\text { Unstandardized } \\
\text { Coefficients }\end{array}$} & \multirow{2}{*}{$\begin{array}{c}\text { Standardized } \\
\text { Coefficients } \\
\text { Beta }\end{array}$} & \multirow[t]{2}{*}{$\mathbf{t}$} & \multirow[t]{2}{*}{ Sig. } \\
\hline & B & Std. Error & & & \\
\hline (Constant) & 68,231 & 4,030 & & 16,932 & ,000 \\
\hline Daring & ,283 & ,072 & ,461 & 3,927 & ,000 \\
\hline
\end{tabular}

Sumber : IBM Statistic SPSS 25

Diperoleh dari kolom $\mathrm{B}$, sehingga persamaan regresi: $\mathrm{Y}=68,231+$ $0,283 \mathrm{X}$. Dari hasil analisis diperoleh thit $=3,927$ dan $\mathrm{p}$-value $=0,000 / 2=0<$ 0,05 atau Ho di tolak. Dengan demikian "Pembelajaran Daring berpengaruh positif terhadap Hasil Belajar mata pelajaran Kewirausahaan".

b) Uji Linearitas dan Signifikansi Persamaan Regresi

Pengujian linearitas dan signifikansi persamaan regresi ditentukan berdasarkan ANOVA table dan ANOVA sebagai berikut:

Tabel 7.

ANOVA Table

\begin{tabular}{|c|c|c|c|c|c|c|c|}
\hline & & & Sum of Squares & df & Mean Square & $\mathbf{F}$ & Sig. \\
\hline \multirow{5}{*}{$\begin{array}{c}\text { Hasil Belajar } \\
\text { Daring }\end{array}$} & \multirow{3}{*}{$\begin{array}{l}\text { Between } \\
\text { Groups }\end{array}$} & (Combined) & 186,343 & 10 & 18,634 & 3,109 & ,004 \\
\hline & & Linearity & 100,921 & 1 & 100,921 & 16,840 & ,000 \\
\hline & & $\begin{array}{l}\text { Deviation from } \\
\text { Linearity }\end{array}$ & 85,422 & 9 & 9,491 & 1,584 &, 147 \\
\hline & \multicolumn{2}{|c|}{ Within Groups } & 287,657 & 48 & 5,993 & & \\
\hline & \multicolumn{2}{|l|}{ Total } & 474,000 & 58 & & & \\
\hline
\end{tabular}

Sumber : IBM Statistic SPSS 25

Hipotesis statistik:

Ho : $\mathrm{Y}=\mathrm{a}+\mathrm{Bx}$ (regresi linear)

Ho : $\mathrm{Y}=\mathrm{a}+\mathrm{Bx}$ (regresi tak linear)

Uji linearitas persamaan garis regresi diperoleh dari baris Deviation from Linearity, yaitu Fhit $(\mathrm{TC})=1,584$, dengan p-value $=0,147>0,05$. Hal ini bearti Ho diterima atau persamaan regresi $\mathrm{Y}$ atas $\mathrm{X}$ adalah linear atau berupa garis linear.

Tabel 8.

ANOVA

\begin{tabular}{ccccccc}
\hline & Model & Sum of Squares & df & Mean Square & F & Sig. \\
\hline 1 & Regression & 100,921 & 1 & 100,921 & 15,419 &, 000 \\
\hline
\end{tabular}




\begin{tabular}{lrrr}
\hline Residual & 373,079 & 57 & 6,545 \\
Total & 474,000 & 58 & \\
\hline Sumber & IBM Statistic SPSS 25 & & \\
& Hipotesis statistik: & & \\
Ho $: \mathrm{b}=0$ (regresi tak bearti) & & \\
Hi $: \mathrm{b}=0$ (regresi bearti) &
\end{tabular}

Uji signifikansi persamaan persamaan garis regresi diperoleh dari baris regression kolom ke-5, yaitu Fhit $(\mathrm{b} / \mathrm{a})=15,419$, dan $\mathrm{p}$-value $=0,000<0,05$ atau Ho ditolak. Dengan demikian, regresi $\mathrm{Y}$ atau $\mathrm{X}$ adalah signifikan atau Pembelajaran daring berpengaruh terhadap hasil belajar mata pelajaran kewirausahaan di SMK Manba'ul Ulum Bekasi.

c) Uji Signifikansi Koefisien Korelasi X dan Y

Tabel 9.

Koefisien Korelasi

\begin{tabular}{|c|c|c|c|c|}
\hline \multicolumn{5}{|c|}{ Model Summary } \\
\hline Model & $\mathrm{R}$ & R Square & Adjusted R Square & Std. Error of the Estimate \\
\hline 1 &, $461^{\mathrm{a}}$ & 213 & 199 & 2,558 \\
\hline
\end{tabular}

Untuk mengetahui berapa persen pengaruh variabel Pembelajaran Daring terhadap Hasil Belajar Mata Pelajaran Kewirausahaan di SMK Manba'ul Ulum Bekasi. Terlihat pada baris pertama koefisien korelari (rxy) = 0,461 dan Fhit (Fchage) $=2,558$, Hal ini bearti Ho ditolak. Koefisien korelasi $\mathrm{X}$ dan $\mathrm{Y}$ adalah bearti atau signifikan. Pada tabel di atas yaitu nilai $\mathrm{R}$ Square $0,213=21,3 \%$.

\section{Discussion}

Dari hasil pengujian penelitian, menunjukkan bahwa hipotesis penelitian ini dapat diterima. Adanya Pengaruh Pembelajaran Daring terhadap Hasil Belajar mata pelajaran Kewirausahaan di SMK Manba'ul Ulum. Terdapat pada Afridayanti (2018) yang menunjukkan bahwa "penerapan pembelajaran daring berpengaruh secara signifikan terhadap hasil belajar". Lin, Chen, \& Liu (2017) yang menunjukan pembelajaran digital atau pembelajaran daring menunjukan efek positif yang lebih baik pada hasil belajar dari pada pengajaran tradisional atau pembelajaran tatap muka. Sutriyani (2020) "pembelajaran daring memiliki pengaruh positif pada minat belajar siswa dan hasil belajar siswa". Nugraha, dkk (2021) "yaitu adanya pengaruh penggunaan media daring terhadap hasil belajar, misalnya kurangnya siswa yang memiliki paket data, guru dan siswa dituntut untuk melakukan proses belajar mengajar menggunakan Pembelajaran Daring". Sobron, dkk (2019) "terdapat pengaruh antara pembelajaran daring terhadap hasil belajar siswa".

Pembelajaran daring menurut Rigianti (2020) yaitu suatu cara baru dalam pembelajaran dengan memanfaatkan perangkat elektronik berupa gawai atau laptop khususnya pada akses internet dalam penyampaiannya dalam pembelajaran, sehingga pembelajaran daring sepenuhnya bergantung kepada akses jaringan internet. Sedangkan menurut Imania \& Bariah (dalam Wardhani, 2020) pembelajaran daring atau (Pembelajaran dalam jaringan) merupakan salah satu bentuk penyampaian pembelajaran secara konvensional kemudian dituangkan kedalam format digital melalui internet. Sehingga pembelajaran daring sebagai satu-satunya media pembelajaran yang efektif 
sehingga dapat menyampaikan materi antara guru dan siswa selama masa darurat pandemic covid-19 ini. Sementara itu, menurut Wardhani (2020) Pembelajaran daring (Dalam jaringan) merupakan bentuk pemanfaatan teknologi, dimana pembelajaran menggunakan akses internet untuk mengatasi berbagai tugas yang telah diberikan oleh pendidik.

Dengan demikian terdapat Pengaruh Pembelajaran Daring berpengaruh positif terhadap Hasil Belajar Mata Pelajaran Kewirausahaan SMK Manba'ul Ulum Bekasi

\section{CONCLUSION}

Penelitian ini merupakan penelitian survey yang dilakukan di SMK Manba'ul Ulum Bekasi. Tujuan dilaksanakan penelitian ini adalah untuk mengungkap pengaruh pembelajaran daring terhadap hasil belajar mata pelajaran kewirausahaan di SMK Manba'ul Ulum Bekasi.

Setelah data penelitian diperoleh dengan menggunakan instrument ukur yang disusun oleh peneliti, maka dilakukan analisis data secara kuantitif, hal ini dilakukan untuk menjawab masalah melalui pengujian terhadap hipotesis penelitian. Dari hasil pengujian hipotesis, maka dapat ditarik kesimpulan sebagai berikut:

Persamaan Regresi Linear. Diperoleh persamaan linear sederhana $\mathrm{Y}=68,231+$ $0,283 \mathrm{X}$. Dari hasil analisis diperoleh thit $=3,927$ dan $\mathrm{p}$-value $=0,000 / 2=0<0,05$ atau Ho di tolak. Dengan demikian "Pembelajaran Daring berpengaruh positif terhadap Hasil Belajar mata pelajaran Kewirausahaan". Hal ini dapat dilihat pada table coefficient dari thit dan p-value lebih kecil dari 0,05.

Koefisien Determinasinya sebesar terdapat pada tabel di atas yaitu nilai R Square $0,213=21,3 \%$ ini berarti variasi variabel hasil belajar mata pelajaran kewirausahaan. Maka dapat disimpulkan bahwa ada hubungan linear secara signifikan antara variabel Pengaruh Pembelajaran Daring (X) dengan Hasil Belajar Mata Pelajaran Kewirausahaan (Y). Ini berarti Pengaruh pembelajaran daring berpengaruh positif terhadap hasil belajar mata pelajaran Kewirausahaan di SMK Manba'ul Ulum.

\section{REFERENCES}

Afridayanti, C. F. (2019). Pengaruh Pembelajaran Daring Dengan Model Reading Questioning And Answering (RQA) Terhadap Hasil Belajar Dan Kemampuan Berpikir Kritis Mahasiswa Pada Mata Kuliah Botani Tumbuhan Tinggi. Etd unsyiah.

Harnani, S. (2020). Efektivitas Pembelajaran Daring Di Masa Pandemi Covid-19. Url: https://bdkjakarta.kemenag.go.id/berita/efektivitas-pembelajaran-daring-di-masapandemi-covid-19. Diakses pada tanggal 20 Agustus 2021.

Januardi, J., \& Zubaimari, R. A. (2018). Pengaruh Mata Pelajaran Prakarya Dan Kewirausahaan Terhadap Minat Berwirausaha Siswa Di SMA Muhammadiyah 02 Palembang. Jurnal Perspektif Pendidikan, 12(2), 1-10.

Lin, M. H., Chen, H. C., \& Liu, K. S. (2017). A study of the effects of digital learning on learning motivation and learning outcome. Eurasia Journal of Mathematics, Science and Technology Education, 13 (7), 3553-3564. DOI:10.12973/eurasia.2017.00744a.

Nugraha, E., Hamidah, E., Radela, N. S., Khopipah, P., \& Sofiyatin, S. (2021). Meningkatkan Motivasi Belajar Dengan Model Pembelajaran Keterampilan Motorik Di Kampung Santri Ciceri Jaya. Ar-Risalah: Media Keislaman, 
Pendidikan dan Hukum Islam, 19(1), 111-127.

Pane, A., \& Dasopang, M. D. (2017). Belajar dan pembelajaran. Fitrah: Jurnal Kajian Ilmu-Ilmu Keislaman, 3(2), 333-352.

Purwanto. (2011). Evaluasi Hasil Belajar. Yogyakarta: Pustaka Pelajar.

Rigianti, H. A. (2020). Kendala Pembelajaran Daring Guru Sekolah Dasar Di Banjarnegara. Elementary School: Jurnal Pendidikan dan Pembelajaran ke-SDan, $7(2)$.

Sobron, A. ., Bayu, Rani, \& Meidawati. (2019). Persepsi Siswa Dalam Studi Pengaruh Daring Learning Terhadap Minat Belajar IPA. SCAFFOLDING: Jurnal Pendidikan Islam Dan Multikulturalisme.

Sugiyono. (2017). Metode Penelitian Pendidikan Pendekatan Kuantitatif, Kualitatif, dan $R \& D$. Bandung: Alfabeta

Suharwoto, Gogot. (2020). Pembelajaran Online di Tengah Pandemi Covid-19, Tantangan yang Uendewasakan. Url: https://pusdatin.kemdikbud.go.id/pembelajaran-online-di-tengah-pandemi-covid19-tantangan-yang-mendewasakan/. Diakses pada tanggal 20 Agustus 2021.

Sutriyani, W. (2020). Studi pengaruh daring learning terhadap minat dan hasil belajar matematika mahasiswa PGSD era pandemi Covid-19. Tunas Nusantara, 2(1).

Vhalery, R., Alfilail, S. N., \& Robbani, H. (2021). Persepsi Mahasiswa tentang Pembelajaran Online Google Classroom pada Minat dan Motivasi Belajar. INTELEKTIUM, 2(1), 28-36.

Vhalery, R., Setyastanto, A. M., \& Alfilail, S. N. (2021). PEMBELAJARAN BERBASIS ONLINE "ZOOM" PADA KESIAPAN BELAJAR MAHASISWA DI MASA PANDEMI COVID-19. Research and Development Journal of Education, 7(1), 215-225.

Wahyono, P., Husamah, H., \& Budi, A. S. (2020). Guru profesional di masa pandemi COVID-19: Review implementasi, tantangan, dan solusi pembelajaran daring. Jurnal pendidikan profesi guru, 1(1), 51-65.

Wardhani, I. S. (2020). Peranan Orang Tua Dalam Pembelajaran Daring Di Sekolah Dasar (Penelitian Kualitatif di Sekolah Dasar Negeri Cikapundung 02 dan Sekolah Dasar Negeri Palalangon) (Doctoral dissertation, FKIP UNPAS). 